\title{
Antimalarial Activity and Nucleoside Transport Inhibitory Activity of the Triterpenic Constituents of Cimicifuga spp.
}

\author{
Masayuki Takahara, ${ }^{a}$ Akiko Kusano, ${ }^{a}$ Makio Shibano, ${ }^{a}$ Genjiro Kusano, ${ }^{*, a}$ Kenzo Kolzumi, ${ }^{b}$ \\ Ryuji Suzuki, ${ }^{b}$ Hye-Sook KIM, ${ }^{c}$ and Yusuke WaTAYA ${ }^{c}$ \\ Osaka University of Pharmaceutical Sciences," 4-20-1 Nasahara, Takatsuki, Osaka 569-1094, Japan, Shionogi Research \\ Laboratories, Shionogi \& Co., Ltd.," Fukushimaku, Osaka 553-0002, Japan, and Faculty of Pharmaceutical Sciences, \\ Okayama University, ${ }^{c}$ 1-1-1 Tushima-naka, Okayama, Okayama 700-8530, Japan. \\ Received February 4, 1998; accepted May 7, 1998
}

The in vitro antimalarial activity against human malaria parasite (Plasmodium falciparum, FCR-3 strain) was examined using 59 triterpenoids obtained during studies on the triterpenic constituents of Cimicifuga spp. The $50 \%$ effective concentration values $\left(\mathrm{EC}_{50}\right)$ of 25 active triterpenoids were $1.0-3.0 \mu \mathrm{M}$, and 19 of the compounds had a common 16, $23: 23,26: 24,25$-triepoxy group in the side-chain moieties. Among the active triterpenoids, 9 also showed significant inhibition of nucleoside transport in mouse splenocytes. A relationship between the antimalarial activity and the inhibition of nucleoside transport involving these triterpenoids is discussed.

Key words Cimicifuga; Ranunculaceae; 9,19-cyclolanostane glycoside; antimalarial activity; nucleoside transport inhibition; thymidine- ${ }^{3} \mathrm{H}$ uptake

The rhizomes of Cimicifuga (C.) simplex, $C$. dahurica, $C$. heracleifolia, and $C$. foetida have been used as a traditional Chinese medicine, Cimicifugae Rhizoma ["Shoma" in Japanese] prescribed for its anti-inflammatory, analgesic and antipyretic effects. ${ }^{1)}$ As some of the chemical constituents of Cimicifuga spp., highly oxygenated 9,19-cyclolanostane glycosides, chromones, caffeic acid derivatives, and cimicifugic acids have been reported. ${ }^{2-6)}$

We reported previously that cimicifugoside and its congeners, obtained from Cimicifuga species, have potent inhibitory effects on the uptake of thymidine and adenosine into phytohemagglutinin (PHA)-stimulated human peripheral lymphocytes $\left(\mathrm{IC}_{50}: 4-5 \mathrm{ng} / \mathrm{ml}\right)$, and some other cell lines. The mechanism has been proved to be potent and selective inhibition of nucleoside transport at the plasma membrane site of mammalian cells. ${ }^{7-9)}$ The inhibitory effect may be promising for reducing the cell growth of the malarial parasite, which relies solely on purine salvage for its survival. ${ }^{10)}$

Therefore, we examined the antimalarial activity of cimicifugoside and its congeners, comparing it with that of other triterpenoids from Cimicifuga spp. We also examined the inhibitory activity of thymidine uptake of the new triterpenoids along with cimicifugoside. In this report we describe the antimalarial activity of these triterpenoids, and the correlation observed between antimalarial activity and the inhibition of thymidine uptake.

\section{MATERIALS AND METHODS}

Chemicals Fifty-nine triterpenic compounds $(\mathbf{1}-\mathbf{5 9})$ of 5 structural groups were examined: cimicifugoside group (group I), shengmanol group (II), hydroshengmanol group (III), cimigenol group (IV), and others (V), as shown in Fig. 1.

Group I: Cimicifugoside (1) and cimicifugenin (17) were obtained from $C$. simplex. ${ }^{11)}$ Actein (2) was obtained from $C$. racemosa and $C$. simplex. ${ }^{12)}$ Bugbanosides A (3) and B (4) were obtained from $C$. simplex. ${ }^{13)}$ 26-Deoxycimicifugoside $(\mathbf{1 5})^{14)}$ was isolated from $C$. simplex and Actaea spicata.

* To whom correspondence should be addressed.
Their related compounds, 5-12, were derived by treatment of 1-4 with $p$-TsOH in $\mathrm{MeOH} .{ }^{12,13)}$ Compounds, 13, 14 and 16, were obtained by oxidation of 1,3 and 4 with pyridine$\mathrm{CrO}_{3}$ solution, and genuine aglycones, 18 and 19, were obtained by hydrolysis of $\mathbf{3}$ and $\mathbf{4}$ with cellulase. ${ }^{13)}$

Group II: 23-O-Acetylshengmanol 3-O- $\beta$-D-glucosyl$(1 \rightarrow 3)$ - $\beta$-D-xyloside (20), 23- $O$-acetylshengmanol-3- $O-\beta$-Dxyloside $(21){ }^{15)} 7 \beta$-hydroxy-23- $O$-acetylshengmanol 3- $O-\beta$ D-xyloside (22), ${ }^{16)}$ and 23-O-acetyl-7,8-didehydro shengmanol 3-O- $\alpha$-L-arabinoside (23), ${ }^{17)}$ were isolated from the aerial parts of $C$. simplex. Their aglycones, 24, and $\mathbf{2 5}$, were obtained by hydrolysis with cellulase. ${ }^{15-17)}$

Group III: 7 $\beta$-Hydroxy-25- $O$-methyl-24- $O$-acetylhydroshengmanol 3-O- $\beta$-D-xyloside $(28),{ }^{18)}$ 24-epi-24- $O$-acetyl7,8-didehydroshengmanol 3-O- $\beta$-D-galactoside $(30),{ }^{17)}$ and the related compounds, $\mathbf{2 6}-\mathbf{2 8}$, were obtained from the aerial parts of $C$. simplex. The aglycones, $\mathbf{3 1 - 3 5}$, were obtained by hydrolysis with cellulase or lactase. ${ }^{17,18)}$

Group IV: $25-O$-Acetylcimigenol 3- $O$ - $\beta$-D-glucosyl- $(1 \rightarrow 3)$ $\beta$-D-xyloside (36), ${ }^{15)} 1 \alpha$-hydroxy-25-O-acetylcimigenol 3- $O$ $\beta$-D-xyloside (38), ${ }^{18)} 12 \beta$-hydroxycimigenol $3-O-\alpha$-L-arabinoside (39), ${ }^{19)} 7 \beta$-hydroxycimigenol $(\mathbf{4 0}),{ }^{16)} \quad 7,8$-didehydrocimigenol $3-O-\beta$-D-galactoside $(43)^{17)}$ and the related compounds, 41 and $\mathbf{4 2}$, were isolated respectively from the aerial parts of $C$. simplex. Cimigenol (49) and 25-O-acetylcimigenol-3- $O-\beta$-D-xyloside (37) were obtained from $C$. simplex, C. acerina and C. japonica. ${ }^{20)} 15$-Deoxycimigenol (51) was derived from 39. The aglycones, $\mathbf{4 5}-\mathbf{5 0}$, were obtained by hydrolysis of the glycosides with cellulase or lactase. ${ }^{15-17)}$

Group V: Cimiaceroside (52) was isolated from C. simplex and $C$. acerina ${ }^{21)}$ Cimiacerol $(\mathbf{5 3})^{21)}$ and $O$-methylcimiacerol $(\mathbf{5 4})^{22)}$ were obtained from $C$. acerina. Acerinol $(\mathbf{5 5})$ and acerinol acetate $(\mathbf{5 6})^{23)}$ were obtained from $C$. acerina, $C$. japonica, and $C$. simplex, $O$-methylcimicimol (57) and simplexol $(\mathbf{5 9})^{20)}$ were derived from $\mathbf{4 1}$, and isodahurinol $(\mathbf{5 8})^{24)}$ was isolated from C. acerina.

Malaria Parasites P. falciparum strain FCR-3 (ATCC30932) was used in this study. The strain was maintained in vitro at $37^{\circ} \mathrm{C}$ in RPMI 1640 medium (Gibco, NY) suple- 
mented with $10 \%$ human serum containing human red blood cells (type A) at 5\% hematocrit using 24 -well microplates. ${ }^{25)}$ The microplates were placed in a $\mathrm{CO}_{2}$ incubator $\left(5 \% \mathrm{CO}_{2}\right.$, $5 \% \mathrm{O}_{2}, 90 \% \mathrm{~N}_{2}$ ) at $37^{\circ} \mathrm{C}$ and the medium was changed daily.

Mammalian Cells A wild-type mouse mammary tumor FM3A cell line (subclone F-28-7), was supplied by the Japanese Cancer Research Resources Bank (JCRB). FM3A cells were maintained in a suspension culture at $37^{\circ} \mathrm{C}$ in a $5 \% \mathrm{CO}_{2}$ atmosphere in plastic bottles containing ES medium supplemented with $2 \%$ heat-inactivated fetal bovine serum (Gibco, NY). ${ }^{26)}$

In Vitro Antimalarial Activity The following procedures were used for routine assay of antimalarial activity. Various concentrations of triterpenoids in distilled water or dimethyl sulfoxide (DMSO) were prepared. $10 \mu \mathrm{l}$ of each solution was added to the individual wells of a 24 -well plate. Erythrocytes with $0.3 \%$ parasitemia were added to each well containing $990 \mu \mathrm{l}$ of culture medium to give a final hematocrit level of $3 \%$. The plates were incubated at $37^{\circ} \mathrm{C}$ in a $5 \%$ $\mathrm{CO}_{2}$ incubator $\left(5 \% \mathrm{CO}_{2}, 5 \% \mathrm{O}_{2}, 90 \% \mathrm{~N}_{2}\right)$. To evaluate the antimalarial activity of the triterpenoids, thin smears were prepared from each culture, stained with Giemsa (E. Merck, Germany), and more than 10000 erythrocytes were examined by microscopy. All the test compounds were assayed in duplicate at each concentration. Drug-free control cultures were run simultaneously. All data points represent the mean of at least two experiments. The fifty percent effective concentration $\mathrm{EC}_{50}$ was determined by comparison with drug-free controls incubated under the same conditions.

Toxicity against a Mammalian Cell Line The population doubling time for FM3A Cells was $12 \mathrm{~h}$. Prior to exposure to drugs, cell density was adjusted to $5 \times 10^{4}$ cells $/ \mathrm{ml}$. A cell suspension of $990 \mu \mathrm{l}$ was dispensed to the test plate, and compounds at various concentrations suspended in either $10 \mu 1$ of distilled water or DMSO, were added to the individual wells of a 24-well plate. The plates were incubated at $37^{\circ} \mathrm{C}$ in a $5 \% \mathrm{CO}_{2}$ atmosphere for $48 \mathrm{~h}$. Cell numbers were measured using a blood cell counter CC-108 (Toa Medical Electric Co., Japan). All data points represent the mean of at least two experiments. The $\mathrm{EC}_{50}$ was determined by comparing with drug-free controls incubated under the same conditions.

Uptake Assay of Radioactive Compounds, Reagents and Procedures The mitogens were concanavalin A (Con A): Sigma, cat. no. C2010, U.S.), lipopolysaccharide (LPS): Difco Laboratories, cat. no. 3920-25-2, U.S., PHA: Gibco, cat. no. 670-0576AD, U.S. Thymidine- ${ }^{3} \mathrm{H}\left({ }^{3} \mathrm{H}-\mathrm{TdR}\right)$ : spec. act., $5 \mathrm{~Bq} / \mathrm{mmol}$, and uridine- ${ }^{3} \mathrm{H}\left({ }^{3} \mathrm{H}-\mathrm{UdR}\right)$ : spec. act., $27 \mathrm{~Bq} / \mathrm{mmol}$ were obtained from Amersham, U.S.

Responder cells: mouse BDF1 (Japan SLC, Inc., Shizuoka, Japan)-splenocyte, male, 8 weeks. The lymphocytes were cultured in microculture plates (Sumitomo Bakelite, cat. no. MS3096-F, Japan). Each well of the microplate received $5 \times 10^{5}$ lymphocytes in $200 \mu \mathrm{l}$ culture medium containing Con A $(5 \mu \mathrm{g} / \mathrm{ml})$, or LSP $(10 \mu \mathrm{g} / \mathrm{ml})$, or PHA $(1 \%)$, together with various concentrations of the test triterpenoids. After $54 \mathrm{~h}$ incubation at $37^{\circ} \mathrm{C}$ in humidified $5 \% \mathrm{CO}_{2}$ in air, $0.5 \mu \mathrm{Bq}{ }^{3} \mathrm{H}-\mathrm{TdR}$, or $0.5 \mu \mathrm{Bq}{ }^{3} \mathrm{H}-\mathrm{UdR}$ was added to each well. Cells were harvested $18 \mathrm{~h}$ later using a multiple semiautomated cell harvestor (Labo Mash, Japan), and the dried glass filter disk in $10 \mathrm{ml}$ Econoflor-2 (Packard Institute, U.S.) was counted in a liquid scintillation counter (Aloka, Japan). The labeled TdR, or UdR incorporation was determined in triplicate cultures and expressed as a relative percentage inhibition $\left(\mathrm{IC}_{50}\right.$ value) with dried free controls incubated under the same conditions.

${ }^{3}$ H-TdR Uptake Assay Responder cells were human PBL cells obtained from a healthy donor. Each well of the microplate received $2 \times 10^{5}$ lymphocyte cells in $200 \mu \mathrm{l} \mathrm{cul-}$ ture medium containing $1 \%$ PHA and the test compound. After $102 \mathrm{~h}$ incubation at $37^{\circ} \mathrm{C}$ humidified in the usual way, $0.5 \mu \mathrm{Bq}{ }^{3} \mathrm{H}-\mathrm{TdR}$ was added to each well. Cells were harvested $18 \mathrm{~h}$ later and the ${ }^{3} \mathrm{H}-\mathrm{TdR}$ uptake was measured as the same as described above.

\section{RESULTS AND DISCUSSION}

Relationship between Chemical Structure and Antimalarial Activity The in vitro antimalarial activity of 59 triterpenoids (1-59, Fig. 1) obtained during the studies on the triterpenic constituents of Cimicifuga spp. were examined against FCR-3 strain ( $P$. falciparum) malarial cultures. Almost all compounds were found to have antimalarial activity in a final concentration range $1-56 \mu \mathrm{M}$ (data not shown). The $\mathrm{EC}_{50}$ values of cimicifugoside-related compounds, 1-19, and some potently active compounds, 20, 22, 36, 44, 46 and 49, among these triterpenoids were found to be in the concentration range $1.0-13.0 \mu \mathrm{M}$, while those of quinine, chloroquine and pyrimethamine as positive controls were $110,18.0$ and $1.0 \mathrm{~nm}$ (Table 1). These data suggest that cimicifugoside (1) and its related compounds have potent antimalarial activity among the triterpenoids of Cimicifuga species, although they were less potent than positive controls such as quinine, chloroquine and pyrimethamine by $2-3$ orders of magnitude. Among the 25 triterpenoids which showed potent antimalarial activity, $19(\mathbf{1}-\mathbf{1 9})$ were classified in group I, $4(\mathbf{3 6}, \mathbf{4 4}, \mathbf{4 6}, \mathbf{4 9})$ in group IV, and $2(\mathbf{2 0}, \mathbf{2 2})$ in group II, while those classified in group V did not show such potent activity.

Their selective toxicity in terms of antimalarial activity $\left(\mathrm{EC}_{50}\right)$ and cytotoxicity aganst FR3A were not so high, while the positive control compounds had indexes of $450-12000$. These results showed that 12 compounds, 1, 2, 4, 9, 10, 13, $14,15,16,20,22$ and 46 , have relatively potent cytotoxicity against FM3A, which seemed inconsistent with the conclusion of a previous report that $5 \mu \mathrm{g} / \mathrm{ml}(7.5 \mu \mathrm{M})$ cimicifugoside (1) had no effect on the growth of L-5178Y cells, cl 1D cells, Raji cells and HeLa S3 cells. ${ }^{9)}$ The $\mathrm{EC}_{50}$ of 1 was $5.0 \mu \mathrm{M}$ against FCR-3 and $30.0 \mu \mathrm{M}$ against FM3A suggesting that 1 should be cytotoxic against both in these concentration range, although 1 inhibited thymidine uptake at almost onethousandth the above concentrations, as mentioned later.

Nucleoside Transport Inhibitory Activity in Vitro The inhibitory effect on ${ }^{3} \mathrm{H}$-TdR uptake in Con A-stimulated mouse splenocytes was examined using 19 triterpenoids (Table 2). Nine compounds $(\mathbf{1}, \mathbf{3}-\mathbf{8}, \mathbf{1 0}$, and 12) of group I were found to have a strong ${ }^{3} \mathrm{H}-\mathrm{TdR}$ transport inhibitory effect on Con A-stimulated lymphocyte proliferation and their $\mathrm{IC}_{50}$ values were in the concentration range $12-1050 \mathrm{ng} / \mathrm{ml}$ $(17.8 \mathrm{~nm}-1.7 \mathrm{~nm})$. Compounds 9 and 11, and 8 compounds, $\mathbf{2 1}, \mathbf{2 2}, \mathbf{3 5}, \mathbf{3 7}-\mathbf{4 0}$, and $\mathbf{5 2}$, of other groups showed far weaker inhibitory effects. 


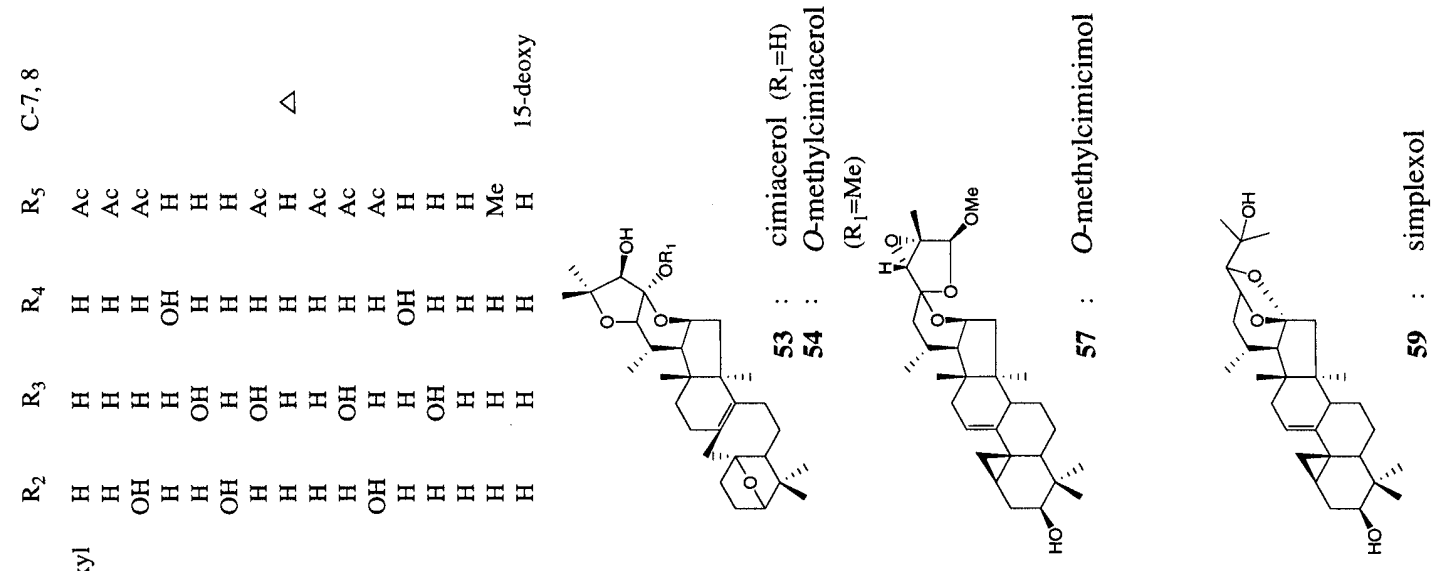

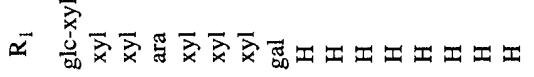

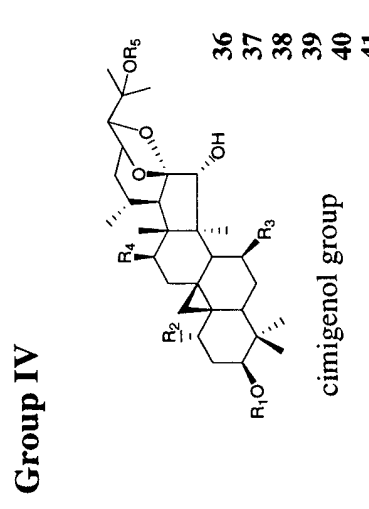

$\stackrel{\infty}{i} \triangleleft \triangleleft \triangleleft \triangleleft \triangleleft \triangleleft \quad \triangleleft \triangleleft \triangleleft$

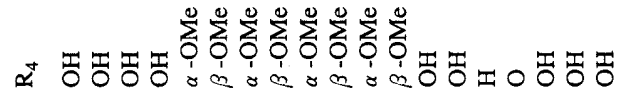

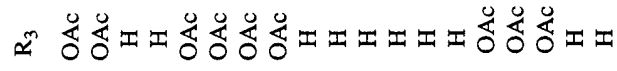

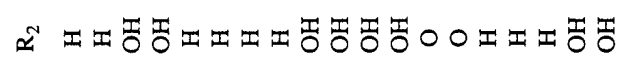

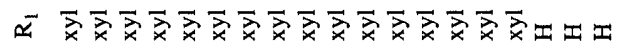

ー

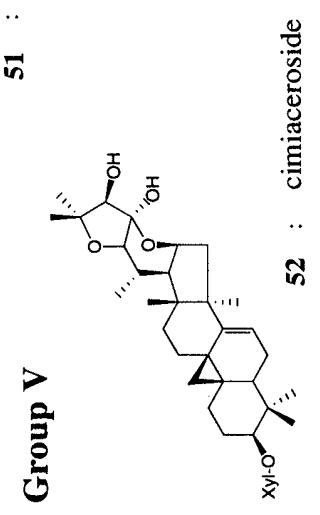

$\stackrel{\infty}{i} \quad \triangleleft$

ณ $\bar{x}$

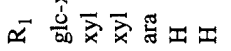

สิสสกสั

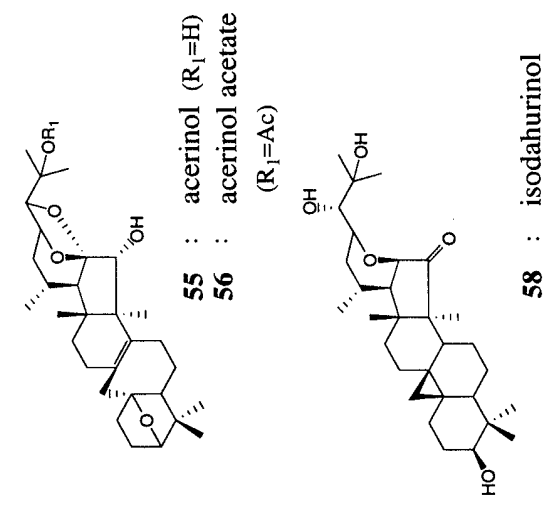

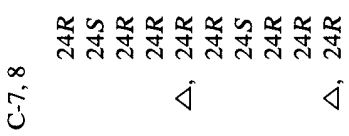

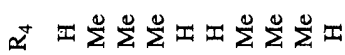

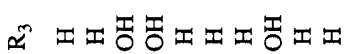

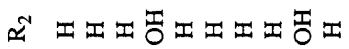

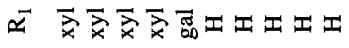

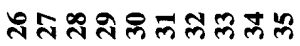
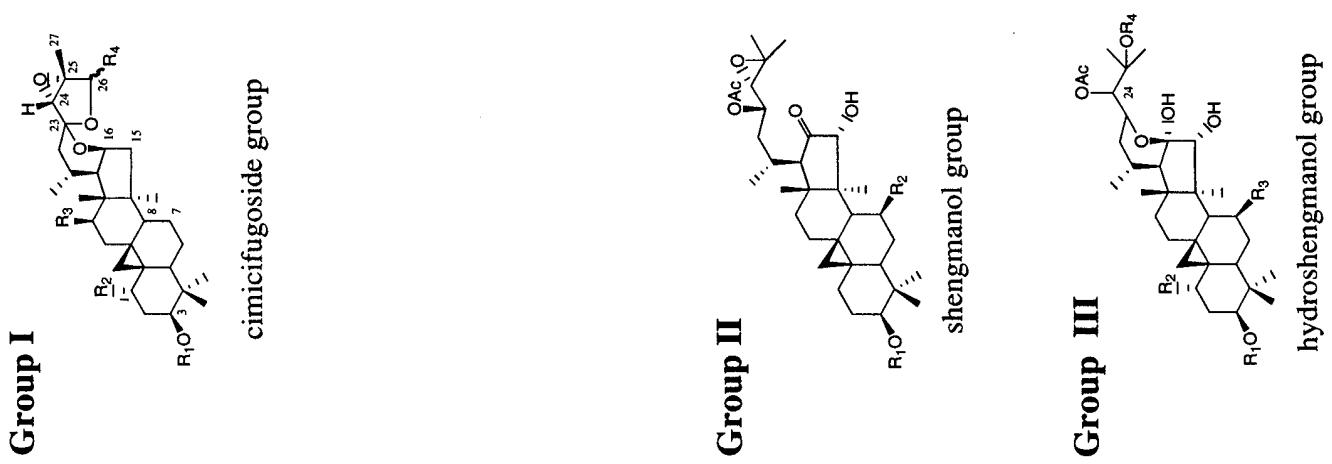
Table 1. Antimalarial Activity and Cytotoxicity of Triterpenoids from Cimicifuga spp. and Their Derivatives

\begin{tabular}{|c|c|c|c|}
\hline Compound & $\begin{array}{c}\text { Antimalarial activity }\left(\mathrm{EC}_{50}\right)^{a)} \\
\left(\mu_{\mathrm{M}}\right)\end{array}$ & $\begin{array}{l}\text { Cytotoxicity }\left(\mathrm{EC}_{50}\right)^{h)} \\
(\mu \mathrm{M})(\text { Cell growth })^{c}\end{array}$ & $\begin{array}{l}\text { Selective toxicity } \\
\text { index }^{(t)}\end{array}$ \\
\hline Cimicifugoside (1) & 5.0 & $30.0(50)$ & 6 \\
\hline Actein $(2)$ & 10.0 & $>10.0(90)$ & $>1$ \\
\hline Bugbanoside A (3) & 2.6 & $>3.0(97)$ & $>1$ \\
\hline Bugbanoside B (4) & 10.0 & $>12.0(100)$ & $>2$ \\
\hline (26S)-O-Methylcimicifugoside (5) & 1.3 & $2.2(50)$ & 2 \\
\hline$(26 S)-O$-Methylactein (7) & 1.0 & $>1.4(87)$ & $>1$ \\
\hline$(26 R)-O-$ Methylactein $(\mathbf{8})$ & 1.8 & $3.3(50)$ & 2 \\
\hline$(26 S)$-O-Methylbugbanoside (9) & 5.0 & $>5.3(96)$ & $>1$ \\
\hline (26R)-O-Methylbugbanoside (10) & 6.0 & $>11.0(81)$ & $>2$ \\
\hline (26S)-O-Methylbugbanoside (11) & 3.0 & $>2.9(86)$ & $>1$ \\
\hline (26R)-O-Methylbugbanoside (12) & 9.0 & $>2.7(100)$ & - \\
\hline 1-Ketobugbanoside A (13) & 6.4 & $>6.4(89)$ & $>1$ \\
\hline Cimicifugoside lactone (16) & 2.1 & $>6.7(68)$ & $>3$ \\
\hline Cimicifugenin (17) & 13.0 & $15.0(50)$ & 1 \\
\hline Bugbanogenin A (18) & 8.0 & - & - \\
\hline Bugbanogenin B (19) & 8.2 & - & - \\
\hline 23-O-Acetylshengmanol-glc-xyl (20) & 4.7 & $>11.0(100)$ & $>2$ \\
\hline 23-O-Acetyl-7 $\beta$-OH-shengmanol-xyl (22) & 12.0 & $>27.0(96)$ & $>2$ \\
\hline 25-O-Acetylcimigenol-glc-xyl (36) & 13.0 & $11.0(50)$ & 1 \\
\hline 25-O-Acetylcimigenol (44) & 1.7 & $1.5(50)$ & 1 \\
\hline 25-O-Acetyl-1 $\alpha$-OH-cimigen (46) & 13.0 & $22.0(50)$ & 2 \\
\hline Cimigenol (49) & 8.0 & $5.0(50)$ & 0.6 \\
\hline Quinine & 0.11 & $50.0(50)$ & 450 \\
\hline Chloroquine & 0.018 & $32.0(50)$ & 1780 \\
\hline Pyrimethamine & 0.001 & $12.0(50)$ & 12000 \\
\hline
\end{tabular}

a) Plasmodium falciparm [FCR-3 (ATCC30932)]; b) mouse mammalian cell (FM3A); c) FM3A cell growth \% at final compound concentration; d) EC For $_{\text {f }}$ FM3A Cell/EC $\mathrm{EC}_{50}$ for Plasmodium falciparm (FCR-3).

Table 2. $\mathrm{IC}_{50}$ of the Triterpenes and Their Derivatives from Cimicifuga spp. on Con A-Stimulated Lymphocyte Proliferation ( ${ }^{3} \mathrm{H}-\mathrm{TdR}$ Uptake Assay)

\begin{tabular}{lr}
\hline \multicolumn{1}{c}{ Compound } & $\mathrm{IC}_{50}(\mathrm{ng} / \mathrm{ml})$ \\
\hline \hline Cimicifugoside (1) & 12 \\
Bugbanoside A (3) & 1050 \\
Bugbanoside B (4) & 750 \\
26(S)-O-Methylcimicifugoside (5) & 210 \\
26(R)-O-Methylcimicifugoside (6) & 25 \\
26(S)-O-Methylactein (7) & 55 \\
26(R)-O-Methylactein (8) & 22 \\
26(S)-O-Methylbugbanoside A (9) & 7800 \\
26(R)-O-Methylbugbanoside A (10) & 660 \\
26(S)-O-Methylbugbanoside B (11) & 7700 \\
26(R)-O-Methylbugbanoside B (12) & 440 \\
23-O-Acetylshengmanol-xyl (21) & 10000 \\
23-O-Acetyl-7 $\beta$-OH-shengmanol-xyl (22) & $>10000$ \\
24-O-Acetylhydroshengmanol-7-xyl (35) & 10000 \\
25-O-Acetylcimigenol-xyl (37) & 9900 \\
25-O-Acetyl-1 $\alpha$-OH-cimigenol-xyl (38) & 10000 \\
12 $\beta$-Hydroxycimigenol-xyl (39) & 9500 \\
7 $\beta$-Hydroxycimigenol-xyl (40) & 8500 \\
Cimiaceroside (52) & $>10000$ \\
&
\end{tabular}

Mouse splenocytes $\left(5 \times 10^{5}\right.$ cells/well) stimulated with Con A $(5 \mu \mathrm{g} / \mathrm{ml})$. After incubation for $54 \mathrm{~h},{ }^{3} \mathrm{H}-\mathrm{TdR}$ was added. Cells were harvested after further incubation for $18 \mathrm{~h}$

These results were similar to the reported data of $\mathbf{1}$ and its related compounds in PHA-stimulated human peripheral lymphocytes and some other cell lines, ${ }^{7,8)}$ and suggested that the 16, 23:23, 26:24 25-triepoxy group in the side-chain was responsible for the activity. It is interesting that compounds, $\mathbf{6}, \mathbf{8}, \mathbf{1 0}$, and $\mathbf{1 2}$, with the $26 R$ configuration were

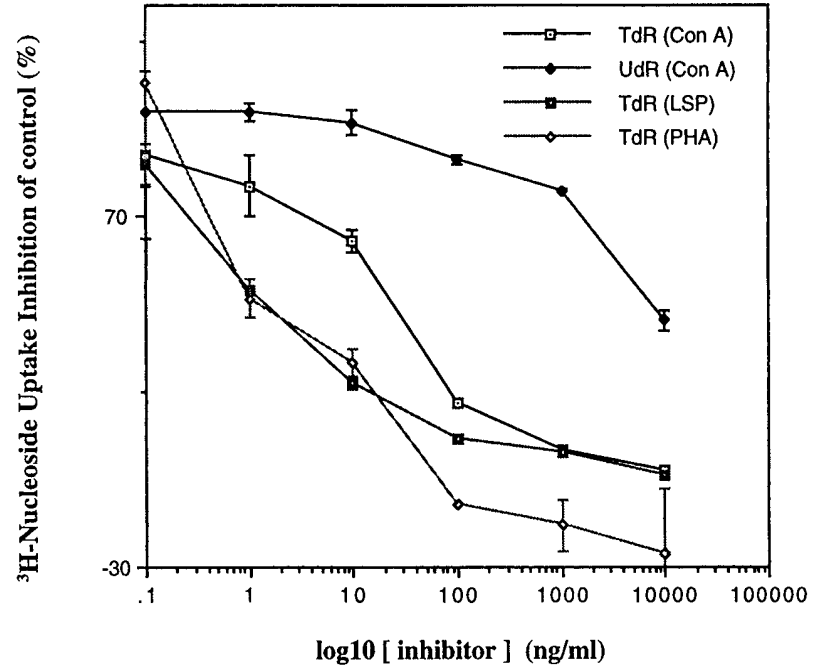

Fig. 2. Effect of Cimicifugoside (1) on Mitogen-Induced Proliferation of Mouse Splenocytes

$\mathrm{TdR}$ (Con A), ${ }^{3} \mathrm{H}$-TdR uptake inhibition into Con A-stimulated splenocytes; UdR (Con A) ${ }^{3} \mathrm{H}$-UdR uptake inhibition into Con A-stimulated splenocytes; TdR (LPS), ${ }^{3} \mathrm{H}$ TdR uptake inhibition into LPS-stimulated splenocytes; TdR (PHA), ${ }^{3} \mathrm{H}-\mathrm{TdR}$ uptake inhibition into PHA-stimulated splenocytes, the procedures and conditions of the ${ }^{3} \mathrm{H}$ uptake inhibition assay are described in "Materials and Methods." Each point represents the mean \pm S.E. of three experiments.

3-18 times more active than compounds, 5, 7, 9, and 11, with the $26 S$ configuration.

Effect of Cimicifugoside (1) on Uptake of ${ }^{3} \mathrm{H}-\mathrm{TdR}$, and ${ }^{3} \mathrm{H}-\mathrm{UdR}$ into Mitogen-Stimulated Human and Mouse Lymphocytes Cimicifugoside (1) inhibited ${ }^{3} \mathrm{H}-\mathrm{UdR}$ and ${ }^{3} \mathrm{H}$-TdR uptake into Con A-stimulated mouse splenocytes 


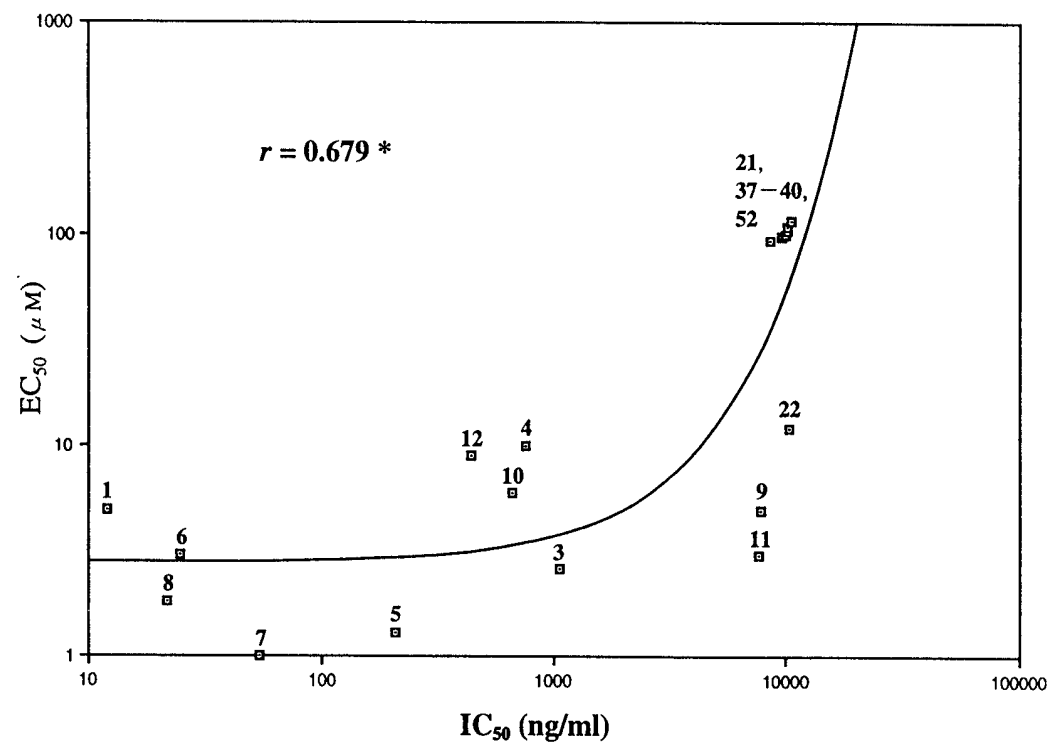

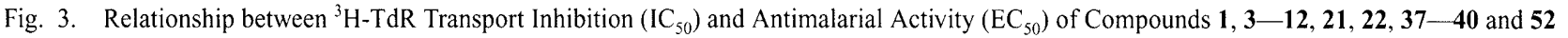

The procedures and conditions of the ${ }^{3} \mathrm{H}-\mathrm{TdR}$ transport inhibition assay are described in "Materials and Methods," and the data on the transport inhibition and antimalarial activity are as described in Tables 2 and 3. An asterisk indicates significance by the bivariate normal distribution $t$-test, $p<0.05$.

Table 3. Effects of Cimicifugoside (1) on Mitogen-Induced Proliferation of Different Cell Lines

\begin{tabular}{ccc}
\hline & \multicolumn{2}{c}{ \% Inhibition } \\
\cline { 2 - 3 } Conc. $(\mathrm{ng} / \mathrm{ml})$ & Human PBL $^{a)}$ & Mouse-splenocyte $^{(h)}$ \\
& 97.7 & 92.5 \\
2000 & 92.2 & 87.9 \\
200 & 69.4 & 63.1 \\
20 & 54.2 & 39.6 \\
2 & 35.8 & 25.0 \\
\hline
\end{tabular}

$\%$ Inhibition is expressed as a relative percentage of inhibition with dried free controls incubated under the same conditions; a) Human PBL $\left(2 \times 10^{5}\right.$ cells/well $)$ stimulated with PHA (1\%). After incubation for $54 \mathrm{~h},{ }^{3} \mathrm{H}-\mathrm{TdR}$ was added. Cells were harvested after further incubation for $18 \mathrm{~h} ; b)$ Mouse splenocytes $\left(5 \times 10^{5}\right.$ cells/well $)$ stimulated with Con A $(5 \mu \mathrm{g} / \mathrm{ml})$. After incubation for $54 \mathrm{~h},{ }^{3} \mathrm{H}-\mathrm{TdR}$ was added. Cells were harvested after further incubation for $18 \mathrm{~h}$.

and PHA-stimulated human peripheral lymphocytes. Additionally, 1 inhibited the ${ }^{3} \mathrm{H}$-TdR uptake in a dose-dependent manner into splenocytes stimulated with LPS and PHA (Fig. 2 , Table 3). These results were similar to those reported with PHA-stimulated human peripheral lymphocytes. ${ }^{7)}$

Almost all tested compounds had antimalarial activity and 25 compounds $\left(\mathbf{1}-\mathbf{2 0}, \mathbf{2 2}, \mathbf{3 6}, \mathbf{4 4}, 46\right.$ and 49) had $\mathrm{EC}_{50}$ values of $1.0-13.0 \mu \mathrm{M}$. Among them, $9(\mathbf{1}, \mathbf{3}-\mathbf{8}, 10$ and 12) had a strong inhibitory effect on nucleoside transport into mitogen-stimulated splenocytes. Because the 9 compounds belong to group I, the partial structure, a $16,23: 23,26: 24$, 25-triepoxy group in the side-chain may be involved in both biological activities. As shown in Fig. 3, there was a relationship between ${ }^{3} \mathrm{H}-\mathrm{TdR}$ transport inhibition $\left(\mathrm{IC}_{50}\right)$ and antimalarial activity $\left(\mathrm{EC}_{50}\right)(r=0.679)$. Statistical evaluation of this correlation coefficient was made using the bivariate normal distribution $t$-test.

Previously we reported that the cimicifugoside (1) and its derivatives were significant inhibitors of ${ }^{3} \mathrm{H}-\mathrm{TdR}$ uptake into mitogen-stimulated lymphocytes, ${ }^{7,8)}$ and the mode of the inhibitory effect on ${ }^{3} \mathrm{H}-\mathrm{TdR}$ uptake proved to be selective inhibition of nucleoside transport of mammalian cells, but not inhibition of DNA synthesis. Therefore, these compounds had little effect on mammalian cell growth, such as human L5178 Y cells, cl 1D cells, Raji cells and HeLa S3 cells. ${ }^{9)}$ These results did not support the hypothesis that the inhibitors of nucleoside transport such as $\mathbf{1}$ and its congeners might selectively inhibit the cell growth of a malarial parasite, which relies solely on purine salvage for its survival. ${ }^{10)}$ In vivo experiments will be needed before a conclusion can be made whether the above inhibitors have selective antimalarial effects or not.

Acknowledgements The authors are grateful to Dr. T. Miyase at the Faculty of Pharmaceutical Sciences, University of Shizuoka, and Mr. K. Minoura at Osaka University of Pharmaceutical Sciences for NMR spectra, and to Mrs. M. Fujitake for mass spectra at Osaka University of Pharmaceutical Sciences. They are also thankful to Mr. H. Hayasaka and Mr. K. Ohba of the Faculty of Pharmaceutical Sciences, Tohoku University, for culturing Cimicifuga spp.

\section{REFERENCES}

1) a) Komatsu K., Li X.-B., Yamaji S., Namba T., Natural Medicines, 50, 222-231 (1996); b) Sakurai N., Nagai M., Yakugaku Zasshi, 116, 850 -865 (1996); c) Kusano G., Kondo K., Takemoto T., Proc. Symp. Wakan-Yaku, 9, 21-27 (1975).

2) Kusano A., Shimizu K., Idoji M., Shibano M., Minoura K., Kusano G., Chem. Pharm. Bull., 43, 279-283 (1995), and references therein.

3) Kondo Y., Takemoto T., Chem. Pharm. Bull., 20, 1940-1944 (1972).

4) Shibata M., Sakurai N., Onoda M., Yakugaku Zasshi, 97, 911-915 (1977).

5) Takahira M., Kusano A., Shibano M., Kusano G., Miyase T., Chem. Pharm. Bull., 46, 362-365 (1998).

6) Kusano G., Shibano M., Idoji M., Minoura M., Heterocycles, 36, 2367-2371 (1993).

7) Hemmi H., Kitame F., Ishida N., Kusano G., Kondo Y., Proc. Symp. Wakan-Yaku, 11, 61-66 (1978).

8) Hemmi H., Kitame F., Ishida N., Kusano G., Nozoe S., J. Pharm. Dyn., 2, 339-349 (1979)

9) Hemmi H., Kusano G., Ishida N., J. Pharm. Dyn., 3, 636-642 (1980).

10) Annette M. G., Joanne M. U., "Purine and Pyrimidine Metabolism in Man VIII," ed. by Sahota A. and Taylor M., Plenum Press, New York, 1995.

11) Kusano G., Hojo Y., Kondo Y., Takemoto T., Chem. Pharm. Bull., 25, 
$3182-3189$ (1977).

12) Kusano A., Takahira M., Shibano M., Miyase T., Kusano G., Chem Pharm. Bull., 46, 467-472 (1998).

13) Kusano A., Takahira M., Shibano M., Miyase T., Kusano G., Chem. Pharm. Bull., 46, 1001-1007 (1998).

14) Kusano A., Takahira M., Shibano M., Miyase T., Kusano G., Chem. Pharm. Bull., submitted.

15) Kusano A., Shibano M., Kitagawa S.,Kusano G., Nozoe S., Fushiya S., Chem. Pharm. Bull., 42, 1940-1943 (1994).

16) Kusano G., Idoji M., Sogoh Y., Shibano M., Kusano A., Iwashita T., Chem. Pharm. Bull., 42, 1106-1110 (1994).

17) Kusano A., Shibano M., Kusano G., Miyase T., Chem. Pharm. Bull., 44, 2078-2085 (1996).

18) Kusano A., Shibano M., Kusano G., Chem. Pharm. Bull., 44, 167172 (1996).
19) Kusano A., Shibano M., Kusano G., Chem. Pharm. Bull., 43, 11671170 (1995).

20) Kusano G., Kondo Y., Takemoto T., Proc. Symp. Wakan-Yaku, 9, 2127 (1975).

21) Kusano A., Takahira M., Shibano M., Miyase T., Okuyama T, Kusano G., Heterocycles, 48, 1003-1013 (1998).

22) Kusano G., Nozoe S., Heterocycles, 20, 1951-1952 (1983).

23) Kusano G., Uchida H., Murakami Y., Sakurai N., Takemoto T., Yakugaku Zasshi, 96, 321-325 (1976).

24) Kusano G., Murakami Y., Sakurai N., Takemoto T., Yakugaku Zasshi, 96, 82 (1976).

25) Trager W., Jensen J. B., Science, 193, 673-675 (1976).

26) Yoshioka A., Tanaka S., Hiraoka O., Koyamada Y., Hirota Y., Ayusawa D., Sen T., Garret C., Wataya Y., J. Biol. Chem., 262, 8235-8241 (1987). 